\title{
Angular Leaf Spot: A Bacterial Disease in Strawberries in Florida ${ }^{1}$
}

\author{
Natalia A. Peres, Silvia I. Rondon, James F. Price, and Daniel J. Cantliffe ${ }^{2}$
}

Angular Leaf Spot (ALS) is a bacterial disease caused by Xanthomonas fragariae Kennedy \& King, a pathogen highly specific to wild and cultivated strawberry, Fragaria x ananassa Duchesne (Legard et al. 2003). ALS is an important disease on winter strawberry production worldwide. In the U.S., it ranks $6^{\text {th }}$ in economic importance after gray mold (Botrytis cinerea L.), verticillium wilt (Verticillium alboatrum Reinke \& Berth), powdery mildew (Sphaerotheca macularis L.), anthracnose (Colletotrichum spp.), and pythium root rot (Pythium spp.) (Sorensen et al. 1997). The rapid spread of ALS is influenced by the increasing rate of interchange of plant material.

ALS was first reported in Minnesota in 1960 and since then it has been found in almost all cultivated strawberry areas in the U.S. (Funt et al. 1997). In California, the largest U.S. producer of fresh strawberries, ALS is a minor disease that occurs especially during rainy weather or when overhead sprinkler irrigation is used (Strand 1993). ALS is the only strawberry disease in Florida caused by a bacterium (Howard et al. 1985). Little is known regarding the epidemiology of ALS (Funt et al. 1997;
Mass 1998); however, development of the disease is favored by warm days $\left(20^{\circ} \mathrm{C} / 68^{\circ} \mathrm{F}\right)$ and cold nights $\left(2-4^{\circ} \mathrm{C} / 36-39^{\circ} \mathrm{F}\right)$ (Howard et al. 1985).

\section{Symptoms}

$X$. fragariae, the causal agent of ALS, is a slow-growing, Gram-negative bacterium that produces water-soaked lesions on the lower leaf surfaces (Figure 1). Lesions begin as small and irregular spots on the undersurface of the leaflets. When moisture is high on the leaves, lesions ooze sticky droplets of bacteria (Howard et al. 1985). As the disease develops, these lesions enlarge and coalese to form reddish-brown spots, which later become necrotic (Figure 2). A practical way to recognize the disease is to place the leaves against a source of background light where the translucent spots can be seen (Figure 3).

During severe epidemics, the pathogen also can cause lesions on the calyx of fruit that are identical to foliar lesions (Figure 4) and when severe, can make the fruit unmarketable (Legard et al. 2003). The tissue with older damage eventually dies and dries up, giving leaves a ragged appearance (Strand 1993).

1. This is document PP-199, a publication of the Plant Pathology Department, Florida Cooperative Extension Service, Institute of Food and Agricultural Sciences, University of Florida. Publication date: June 2004. Please visit the EDIS Website at http://edis.ifas.ufl.edu.

2. Natalia A. Peres, assistant professor, Gulf Coast Research Center and Education Center; Silvia I. Rondon, post doctorate, Horticultural Sciences Department; James F. Price, associate professor, Gulf Coast Research and Education Center; Daniel J. Cantliffe, professor, Horticultural Sciences Department.

The Institute of Food and Agricultural Sciences (IFAS) is an Equal Employment Opportunity - Affirmative Action Employer authorized to provide research, educational information and other services only to individuals and institutions that function without regard to race, creed, color, religion, age, disability, sex, sexual orientation, marital status, national origin, political opinions or affiliations. For information on obtaining other extension publications, contact your county Cooperative Extension Service office. Florida Cooperative Extension Service / Institute of Food and Agricultural Sciences / University of Florida / Larry R. Arrington, Interim Dean 


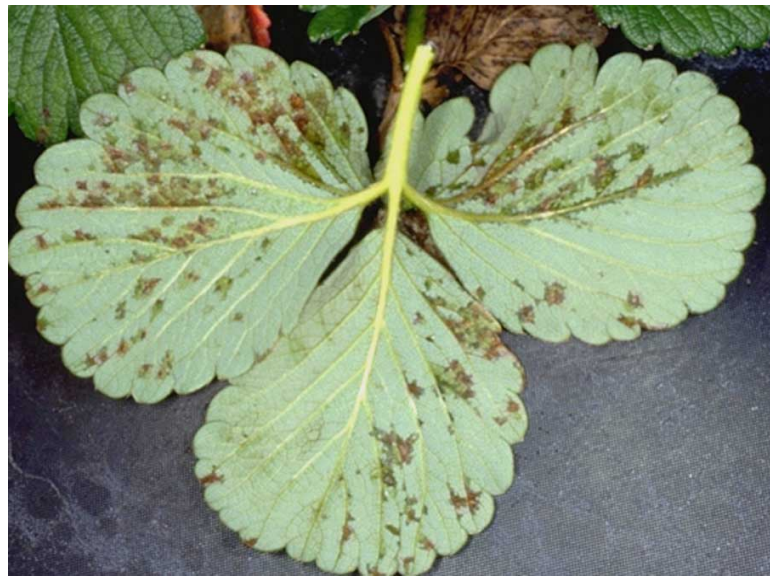

Figure 1. Water soaked lesions of Angular Leaf Spot. Credits: Univ. of Florida, GCREC

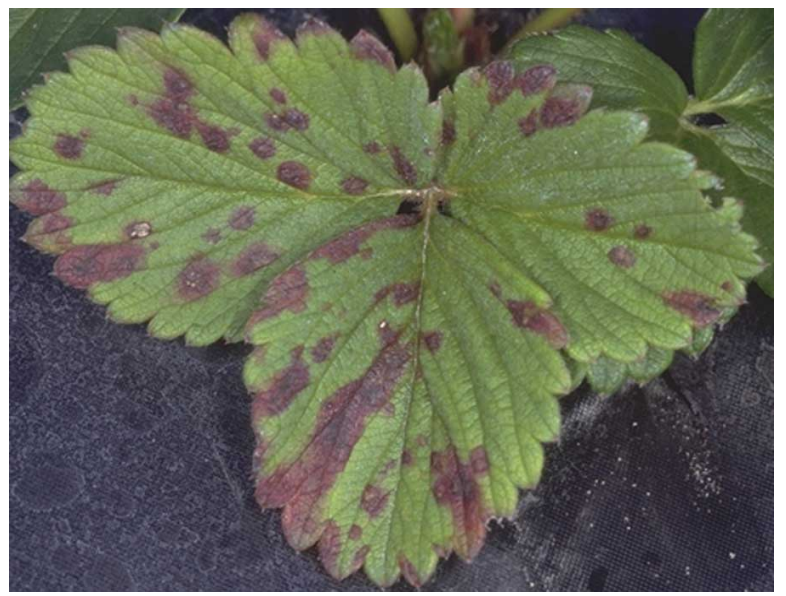

Figure 2. Reddish-brown spots of Angular Leaf Spot. Credits: Univ. of Florida, GCREC

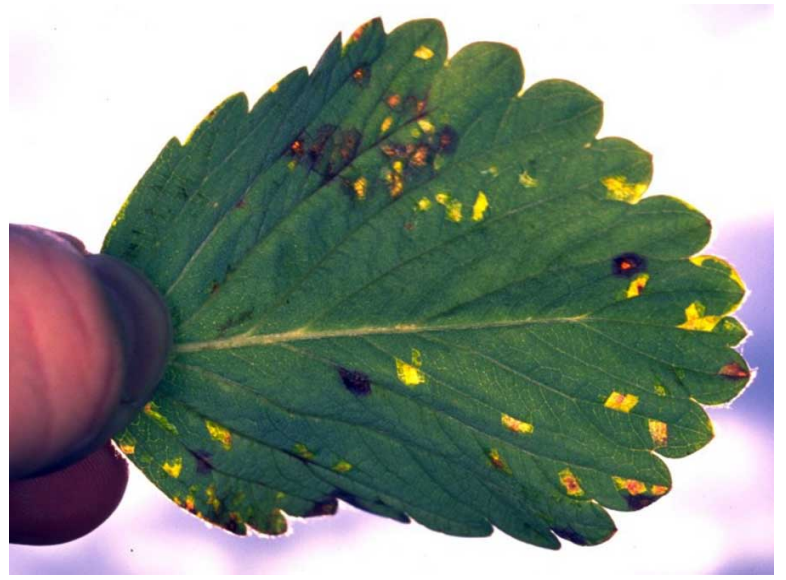

Figure 3. Translucent spots of Angular Leaf Spot. Credits: Univ. of Florida, GCREC

\section{Spread of the Disease}

The primary source of inoculum in a new field is contaminated transplants (Mass 1998). Secondary inoculum comes from bacteria that exude from

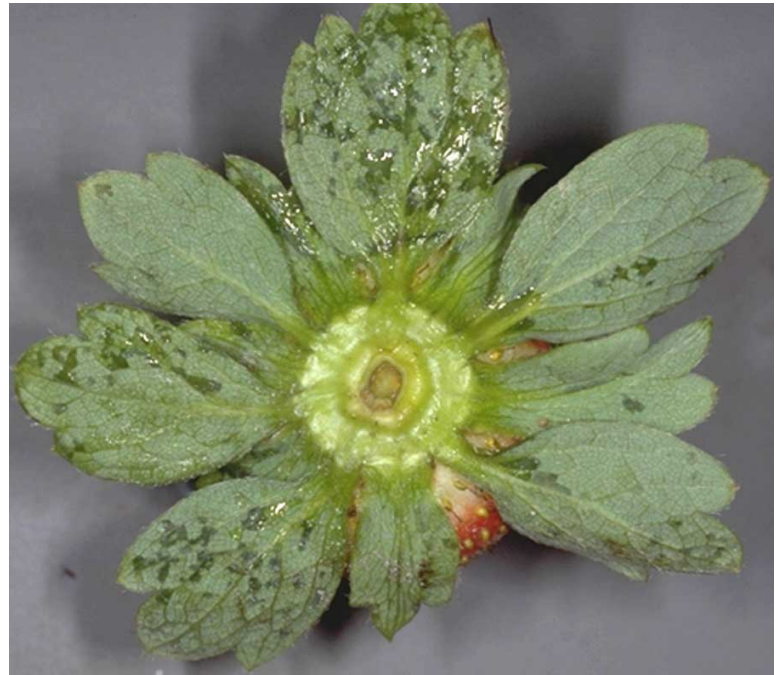

Figure 4. Water soaked lesion of Angular Leaf Spot on the calyx. Credits: Univ. of Florida, GCREC

lesions under high moisture conditions. Bacteria can survive on dry infested leaves and tissue buried in the soil for up to 1 year (Roberts et al. 1997; Strand 1993). The pathogen can be spread easily by harvesting operations when wet and cool conditions favor the production of bacterial exudate. The pathogen also can be dispersed by rain and overhead sprinkler irrigation. If the disease invades the vascular system of the plant, the disease will be difficult to control. Affected plants may wilt and die.

\section{Control Methods}

The best way to control ALS is to use pathogen-free transplants. Hydrogen dioxide and copper-based products can provide effective control of the disease in some instances, but low rates of copper should be used since phytotoxicity has been documented with repeated sprays. Growers should avoid harvesting and moving equipment through infected fields when the plants are wet. Minimizing the use of overhead sprinklers during plant establishment and for freeze protection will also reduce the spread of the disease.

\section{Literature Cited}

Funt, R.C., M.A. Ellis, and C. Welty. 1997. Midwest small fruit pest management handbook. Ohio State University. 196 pp. 
Howard, C.M., A.J. Overman, J.F. Price, and E.E. Albregts. 1985. Diseases, nematodes, mites, and insects affecting strawberries in Florida. University of Florida, Agricultural Experimental Station, Institute of Food and Agricultural Sciences. 51 pp.

Legard, D.E., M. Ellis, C.K. Chandler, and J.F. Price. 2003. Integrated management of strawberry diseases in winter fruit production areas, Pp 111-124. In The Strawberry: a book for growers. N. Childers (ed.). Institute of Food and Agricultural Sciences, Horticultural Sciences Department, University of Florida, Gainesville. Norm Childers Publications. $246 \mathrm{pp}$.

Mass, J.L. 1998. Compendium of strawberry diseases. $2^{\text {nd }}$ edition. APS press, St Paul, MN.

Roberts, P.D., R.S. Berger, J.B. Jones, C.K. Chandler, and R.E. Stall. 1997. Disease progress, yield loss, and control of Xanthonoma fragariae on strawberry plants. Plant Dis. 81: 917-921.

Strand, L.L. 1993. Integrated pest management for strawberries. University of California, State Wide Integrated Pest Management Project. Division of Agriculture and Natural Resources. Publication 3351. $142 \mathrm{pp}$.

Sorensen, K. A., W.D. Gluber, N.C. Welch and C. Osteen. 1997. The importance of pesticides and other pest management practices in U.S. strawberry production. North Carolina Cooperative Extension Service. NAPIAP 1-CA-97. 242 pp. 